$\xi=$ 圆

\title{
Antibiotic susceptibility, plasmid isolation and curing of some foodborne pathogens
}

\author{
Ebakota Omonigho Daniel ${ }^{1}$, Osarueme Johnson Osazee ${ }^{1,2}$, Frances N. Olisaka ${ }^{1}$, Panmwa Bilihatu Galau ${ }^{1}$, \\ Jocelyn Amenze Aibangbee ${ }^{2}$, Joseph Osamudiamen Osazee ${ }^{3,4 *}$ \\ ${ }^{1}$ Microbiology Option, Faculty of Basic and Applied Sciences, Benson Idahosa University. P.M.B 1100, Benin City, Nigeria \\ ${ }^{2}$ Department of Biostatistics and Epidemiology, College of Public Health, East Tennessee State University, Johnson City, TN, 37614, U.S.A \\ ${ }^{3}$ Department of Chemistry, East Tennessee State University, Johnson City, TN, 37614, U.S.A \\ ${ }^{4}$ Department of Plant Biology and Biotechnology, Faculty of Life Sciences, University of Benin, P.M.B 1154, Benin City, Nigeria \\ *Corresponding author E-mail: osazeej@etsu.edu
}

\begin{abstract}
The indiscriminate use of antibiotics by individuals as well as in food production has been tagged one of the major reasons for the spread of antibiotic resistance in pathogens. Thus, there is a concern that foodborne bacteria may act as reservoirs of antibiotic resistance genes when distributed in large doses with food. This study aimed at determining the antibiotic susceptibility, plasmid isolation and curing of foodborne bacteria isolated from ready to eat (RTE) foods and salads in eating centers at the Benson Idahosa University, Benin City. Isolates were Enterobacter aerogenes, Escherichia coli, Staphylococcus aureus, Bacillus spp., Micrococcus sp. and Salmonella sp with S. aureus occurring most frequently. Total resistance to cefuroxime and augmentin as well as considerable resistance to ceftazidime and cefixime were observed in all isolates in antimicrobial susceptibility tests were done on Mueller-Hinton agar. Relative sensitivity to gentamicin, ofloxacin, nitrofurantoin and ciprofloxacin were observed. Plasmid profiling indicated that all isolates possess plasmids ranging from $100 \mathrm{bp}$ to $1 \mathrm{kbp}$. Plasmid curing using sodium dodecyl sulfate (SDS) improved the sensitivity of isolates to antibiotics they were previously sensitive to but most isolates remained resistance to ceftazidime, cefuroxime, cefixime, and augmentin. This study shows that foodborne bacteria can possess and possibly transfer persistent antibiotic resistance plasmids thus calling for more caution in the use of antibiotics in food production and reduced antibiotics abuse. Further research is currently ongoing to cure the isolates of all plasmids and to elucidate how these plasmids are being transferred.
\end{abstract}

Keywords: Antibiogram; Antibiotic Resistance; Coliform; Plasmid; Ready to Eat Food.

\section{Introduction}

Ready to eat (RTE) foods can also be described as food raw or cooked, hot or chilled that is ready for immediate consumption at the point of sale without further treatment (Tsang 2002). There are certain appealing factors that make street foods popular as food sources; familiarity, taste, low cost and convenience (Mahakarnchanakul et al. 2010). Our society shows a social pattern characterized by increased mobility, many itinerary workers and less family or home-centered activities. This situation, however, has resulted in more ready-to-eat foods taken outside the home. Thus, food vendor services are on the increase and the responsibility of good manufacturing practices of food including good sanitary measures and proper handling have been transferred from individuals/families to the food vendors who rarely enforce such practices (Musa \& Akande 2002).

In Nigeria, most of these products are stored under non-hygienic conditions. They are often displayed in open trays or container in the market or are hawked along the street and major runways. Contamination of food can occur at any point in the production chain (i.e. from the raw materials, processing, packing, transportation, storage or marketing) to consumption. Because of improper processing, handling and storage of these foods could be subject to contamination by the microorganism (Musa \& Akande 2002).
Food consumption is an important pathway for bacteria to infect humans, hence the presence of antimicrobial resistant bacteria in foods warrants attention. Antimicrobial resistant bacteria have been recovered from both healthy humans and a wide variety of foods, which include vegetables, confectionary, meat and meat products and poultry (Pinegar \& Cooke 1985, Osterblad et al. 1999, Okeke et al. 2000). Hence, food contaminated by faecal material from healthy humans may be an important source of antibiotic resistant organisms that later cause human infection (Teuber 1999, Schoeder et al. 2004).

Contamination of ready-to-eat food is of primary concern because such organisms may be pathogenic thereby leading to the outbreak of food-borne illness. Moreover, non-pathogenic organisms that may contaminate man's food chain from time to time may serve as a reservoir of genes for antimicrobial resistance in organisms. These genes are encoded by integrons that occur on plasmids or that are integrated into the bacterial chromosome (Goldstein et al. 2001). Antimicrobial resistant strains of animal or human commensals that do not produce disease may transmit their resistance genes to pathogenic organisms whenever they occur in humans. Thus, the aim of this research was to isolate and characterize microorganisms present in RTE rice and salads sold at Benson Idahosa University, determine the antibiogram pattern of the isolated organisms and to study possible plasmid profile of multi-drug resistant isolates. 


\section{Materials and methods}

\subsection{Sample area description}

Benson Idahosa University, Benin City is located at latitude 5045 $1 \mathrm{~N}$ and longitude $50641 \mathrm{E}$ in Edo State, Nigeria. The research was carried out in the Microbiology laboratory, in the month of March 2014. Rice and salads samples were purchased from different food sales outlet or restaurants within the campus.

\subsection{Sample collection}

Samples of RTE Rice and Salad were collected from four different restaurants located at Benson Idahosa University premises, Benin City Nigeria and were named: Sample A, B, C, and D respectively. RTE rice samples were labeled $\mathrm{A} 1, \mathrm{~B} 1, \mathrm{C} 1$, and $\mathrm{D} 1$ respectively while salads were labeled A2, B2, C2 and D2. RTE rice and salad samples were collected in clean polyethylene bags and aseptically transported to the laboratory for analysis.

\subsection{Isolation of microorganisms}

Serial dilutions of all the samples were carried out using stock solutions made from $1 \mathrm{~g}$ in $9 \mathrm{ml}$ sterile distilled water of each sample. $1 \mathrm{ml}$ each of selected dilutions was plated using the pour plate method (Harrigan \& McCane 1976). Enumeration of the total aerobic viable count was done using Nutrient agar. Eosin methylene blue (EMB) agar was used for E. coli count, Salmonella - Shigella agar was used for Salmonella and Shigella count and MacConkey agar for the coliform count. All cultures were incubated in duplicate at $37^{\circ} \mathrm{C}$ for 24 hours except for coliform organism(s) which were incubated at $37^{\circ} \mathrm{C}$ and $44{ }^{\circ} \mathrm{C}$ for 24 hours. All media used were prepared per the manufacturers' instructions Isolates were identified through a morphological appearance on media, gram staining, and biochemical tests. Pure cultures of isolates were obtained by sub-culturing by repeated streaking. Pure cultures were then transferred to slant for storage and kept in the refrigerator until when needed for further analysis.

\subsection{Antibiotic susceptibility test}

The antibiotic sensitivity pattern of the isolates was determined using the disc diffusion method. Mueller Hinton agar plates were prepared and appropriately labeled. The plates were inoculated with the standardized bacterial cultures by spread plate technique (Harley \& Prescott 2002). The inoculated plates were left to dry for 15 minutes. Commercially available antibiotics disc containing varying concentration of various types of antibiotics were placed at adequate distances on each of the seeded agar plates with the aid of sterile forceps under aseptic conditions the antibiotics disc was; Ceftazidime (caz) $(30 \mu \mathrm{g})$, Cefuroxime (crx) $(30 \mu \mathrm{g})$, Gentamicin (Gen) $(10 \mu \mathrm{g})$, cefixime (cxm) $(5 \mu \mathrm{g})$, Ofloxacin (ofl) (5 $\mu \mathrm{g}$ ), augmentin (aug) $(30 \mu \mathrm{g})$, nitrofurantoin (Nit) $(300 \mu \mathrm{g})$, ciprofloxacin (cpr) $(5 \mu \mathrm{g})$. The plates were incubated for 24 hours. The resultant visible zones of inhibition were measured in millimeters $(\mathrm{mm})$. Zones of inhibition greater than $14 \mathrm{~mm}$, ranging from $14-17 \mathrm{~mm}$ and greater than $17 \mathrm{~mm}$ were regarded as resistant (R), intermediate (I) and susceptible respectively (Harley \& Prescott 2002).

\subsection{Plasmid isolation}

Cells were grown on nutrient agar and harvested with $200 \mu \mathrm{L}$ of buffer 1A (400 Mm Tris, $200 \mathrm{Mm}$ Na EDTA and acetic acid to $\mathrm{pH}$ 8.0). The cells were then vortex and $400 \mu \mathrm{L}$ of lysing solution (4 $\%$ SDS, $100 \mathrm{Mm}$ Tris) were added, centrifuged at 14,000 $\mathrm{g}$ for $5 \mathrm{~min}$. the supernatant were collected in fresh eppendorf tubes and $700 \mu \mathrm{L}$ of chloroform were added and vortexed. After which it was left on ice for 1 hour and centrifuged at 14,000 g for 5 minutes. The aqueous layers were collected in fresh eppendorf tubes. To $500 \mu \mathrm{L}$ of aqueous layer, $1 \mathrm{ml}$ absolute ethanol was added and tubes keep in ice for 1 hour. Tubes were centrifuged again at $14000 \mathrm{~g}$ for 5 minutes and the supernatant decanted. The pellets were washed in $70 \%$ ethanol and air - dried. Afterwards, $100 \mu \mathrm{L}$ of buffer $3 \mathrm{C}$ was added to the pellets.

\subsection{Gel electrophoresis}

$0.8 \%$ agarose gel was prepared and two drops of ethidium bromide were added after which it was allowed to gel. $10 \mu \mathrm{L}$ of the samples mixed with loading dye was loaded in each well. Then 10 $\mu \mathrm{L}$ of the DNA ladder was loaded on the last well. The electrophoresis ran at $90 \mathrm{v}$ for 30 mins after which gel photographs were taken under Ultraviolet (UV) light.

\subsection{Plasmid curing}

All isolates that were observed to harbour plasmid were subjected to plasmid curing per the method of Chin et al. (2005). The chemical agent used for the plasmid curing was SDS.

\section{Results and discussion}

The total counts, coliform count and Salmonella-Shigella count of ready to eat rice samples are shown in Table 1 . The counts ranged from $6.0 \times 10^{3}$ to $5.8 \times 10^{4}$ colony forming units $(\mathrm{CFU}) / \mathrm{g}$ (Table 1$)$. Sample A1 has the highest count of $5.8 \times 10^{4} \mathrm{CFU} / \mathrm{g}$; followed by sample B1 $\left(1.7 \times 10^{4} \mathrm{CFU} / \mathrm{g}\right)$ and $\mathrm{C} 1\left(1.5 \times 10^{4} \mathrm{CFU} / \mathrm{g}\right)$ while sample D1 had the lowest count of $6.0 \times 10^{3} \mathrm{cfu} / \mathrm{g}$. The coliform count ranged between zero and $1.1 \times 10^{4} \mathrm{CFU} / \mathrm{g}$. Sample A had a coliform count of $1.1 \times 10^{3} \mathrm{CFU} / \mathrm{g}$ while there were no coliform counts in Sample B1, C1, and D1.

The total counts, coliform count and Salmonella-Shigella count of ready to eat salad samples are shown in Table 2. The counts ranged between $2.2 \times 10^{4}$ to $8.9 \times 10^{4} \mathrm{CFU} / \mathrm{g}$. Sample B2 has the highest count of $8.9 \times 10^{4} \mathrm{CFU} / \mathrm{g}$; followed by sample A2 $\left(7.1 \times 10^{4}\right)$ and C2 $\left(6.4 \times 10^{4}\right)$ while sample D1 had the lowest count of $2.2 \mathrm{x}$ $10^{4} \mathrm{CFU} / \mathrm{g}$. The coliform count ranged between $2.2 \times 10^{3}$ to $4.3 \times 10^{3} \mathrm{CFU} / \mathrm{g}$. Sample B2 has the highest coliform count of $4.3 \times 10^{3} \mathrm{CFU} / \mathrm{g}$, followed by Sample C2 $\left(4.0 \times 10^{3}\right)$ and A $(3.6 \mathrm{x}$ $10^{3}$ ) while sample D2 had the lowest coliform count of $2.2 \times 10^{3}$ $\mathrm{CFU} / \mathrm{g}$, as shown in Table 1. The Salmonella-Shigella (SS) count ranged from $5.9 \times 10^{2}$ to $9.9 \times 10^{2} \mathrm{CFU} / \mathrm{g}$. Sample A2 had the having highest Salmonella-Shigella count of $9.9 \times 10^{2} \mathrm{CFU} / \mathrm{g}$, followed by sample B2 $\left(5.9 \times 10^{2}\right)$ while sample C2 and D2 had a no SS count respectively. 
Table 1: Total Counts, Salmonella-Shigella (SS) Counts and Total Coliform Counts of the Ready to Rice

\begin{tabular}{|c|c|c|c|c|}
\hline Sample & Total bacterial counts (CFU/g) & Coliform count $(\mathrm{CFU} / \mathrm{g})$ & $\begin{array}{l}\text { Salmonella-Shigella } \\
\text { count (CFU /g) }\end{array}$ & E.coli counts (CFU /g) \\
\hline A 1 & $5.8 \times 10^{4} \pm 0.0$ & $1.1 \times 10^{4} \pm 0.0$ & Nil & Nil \\
\hline B 1 & $1.7 \times 10^{4} \pm 0.0$ & Nil & Nil & Nil \\
\hline C 1 & $1.5 \times 10^{4} \pm 0.0$ & Nil & Nil & Nil \\
\hline D 1 & $6.0 \times 10^{3} \pm 0.0$ & Nil & Nil & Nil \\
\hline
\end{tabular}

Table 2: Total Counts, Salmonella-Shigella (SS) Counts and Total Coliform Counts of the Ready to Eat Salads

\begin{tabular}{llll} 
& Table 2: Total Counts, Salmonella-Shigella (SS) Counts and Total Coliform Counts of the Ready to Eat Salads \\
\hline Sample & Total bacterial counts $(\mathrm{CFU} / \mathrm{g})$ & $\begin{array}{l}\text { Coliform count } \\
(\mathrm{CFU} / \mathrm{g})\end{array}$ & $\begin{array}{l}\text { Salmonella-Shigella } \\
\text { count (CFU/g) }\end{array}$ \\
\hline A 2 & $7.1 \times 10^{4} \pm 0.2$ & $3.6 \times 10^{3} \pm 1.0$ & $9.9 \times 10^{2} \pm 0.1$ \\
B 2 & $8.9 \times 10^{4} \pm 0.2$ & $4.3 \times 10^{3} \pm 0.0$ & $5.9 \times 10^{2} \pm 0.1$ \\
C 2 & $6.4 \times 10^{4} \pm 0.4$ & $4.0 \times 10^{3} \pm 0.6$ & Nil \\
D 2 & $2.2 \times 10^{4} \pm 0.3$ & $2.2 \times 10^{3} \pm 1.0$ & Nil \\
\hline
\end{tabular}

Table 3: Frequency of Occurrence of Bacteria Isolates

\begin{tabular}{|c|c|c|c|c|c|c|}
\hline \multirow{2}{*}{ Bacterial isolates } & \multirow[t]{2}{*}{ No. of isolates } & \multicolumn{4}{|c|}{ Samples } & \multirow{2}{*}{ Frequency of occurrence $(\%)$} \\
\hline & & A & $\mathrm{B}$ & $\mathrm{C}$ & $\mathrm{D}$ & \\
\hline S. aureus & 4 & + & + & + & + & 33.3 \\
\hline E. aerogenes & 2 & - & + & + & - & 16.7 \\
\hline Salmonella sp. & 4 & + & + & + & + & 16.7 \\
\hline Micrococcus sp. & 1 & - & + & - & - & 8.3 \\
\hline B. cereus & 1 & - & + & - & - & 8.3 \\
\hline E. coli & 2 & + & + & - & - & 16.7 \\
\hline Total & 14 & 3 & 6 & 3 & 2 & 100 \\
\hline
\end{tabular}

Enterobacter aerogenes, E. coli, Staphylococcus aureus, Bacillus spp., Micrococcus sp. and Salmonella sp. were isolated and identify from both RTE rice and salads obtained from samples from all the restaurants. The frequency of occurrence of the bacteria isolated from the ready to eat salad samples is shown in Table 3. Staphylococcus aureus (33.3\%) was most frequently occurring isolate while Bacillus cereus $(8.3 \%)$ was the least occurring isolate.

Table 4: Antibiotic Susceptibility Pattern of the Bacterial Isolates

\begin{tabular}{|c|c|c|c|c|c|c|c|c|c|}
\hline Isolates code & GEN & CAZ & CRX & CXM & OFL & AUG & NIT & CPR & Isolates \\
\hline K.1 & $\mathrm{S}$ & $\mathrm{R}$ & $\mathrm{R}$ & $\mathrm{R}$ & $\mathrm{S}$ & $\mathrm{R}$ & $\mathrm{R}$ & $\mathrm{S}$ & S. aureus \\
\hline K.2 & S & $\mathrm{R}$ & $\mathrm{R}$ & $\mathrm{R}$ & S & $\mathrm{R}$ & $\mathrm{R}$ & S & S. aureus \\
\hline K.3 & S & S & $\mathrm{R}$ & S & S & $\mathrm{R}$ & I & S & S. aureus. \\
\hline K.4 & S & $\mathrm{R}$ & $\mathrm{R}$ & $\mathrm{R}$ & S & $\mathrm{R}$ & I & $\mathrm{R}$ & S. aureus. \\
\hline H 1 & I & $\mathrm{R}$ & $\mathrm{R}$ & $\mathrm{R}$ & S & $\mathrm{R}$ & S & S & E. aerogenes \\
\hline H.2 & S & $\mathrm{R}$ & $\mathrm{R}$ & $\mathrm{R}$ & $\mathrm{R}$ & $\mathrm{R}$ & $\mathrm{R}$ & S & E. aerogenes \\
\hline B.1 & S & $\mathrm{R}$ & $\mathrm{R}$ & I & I & $\mathrm{R}$ & S & S & Salmonella sp. \\
\hline B. 2 & S & $\mathrm{R}$ & $\mathrm{R}$ & $\mathrm{R}$ & S & $\mathrm{R}$ & S & S & Salmonella sp. \\
\hline 0.1 & $\mathrm{~S}$ & $\mathrm{R}$ & $\mathrm{R}$ & $\mathrm{R}$ & S & $\mathrm{R}$ & I & S & Micrococcus sp. \\
\hline B. 1 & $\mathrm{R}$ & $\mathrm{R}$ & $\mathrm{R}$ & $\mathrm{R}$ & S & $\mathrm{R}$ & $\mathrm{R}$ & S & B. cereus \\
\hline E.1 & $\mathrm{S}$ & $\mathrm{R}$ & $\mathrm{R}$ & $\mathrm{R}$ & S & $\mathrm{R}$ & S & S & E. coli \\
\hline E. 2 & S & $\mathrm{R}$ & $\mathrm{R}$ & $\mathrm{R}$ & $\mathrm{R}$ & $\mathrm{R}$ & $\mathrm{R}$ & S & E. coli \\
\hline
\end{tabular}

KEY: R = Resistant, $\mathrm{S}=$ Sensitive, I = Intermediate

Table 5: Zone of Inhibition in Mm for Antibiotic Susceptibility Pattern of the Bacterial Isolates

\begin{tabular}{|c|c|c|c|c|c|c|c|c|}
\hline Isolates codes & GEN & CAZ & CRX & CXM & $\overline{\mathrm{OFL}}$ & AUG & NIT & CPR \\
\hline K 1 & 23 & $\mathrm{R}$ & $\mathrm{R}$ & $\mathrm{R}$ & 28 & $\mathrm{R}$ & $\mathrm{R}$ & 35 \\
\hline K 2 & 25 & $\mathrm{R}$ & $\mathrm{R}$ & $\mathrm{R}$ & 28 & $\mathrm{R}$ & $\mathrm{R}$ & 35 \\
\hline K 3 & 25 & 25 & $\mathrm{R}$ & 20 & 25 & $\mathrm{R}$ & 15 & 30 \\
\hline K 4 & 25 & $\mathrm{R}$ & $\mathrm{R}$ & $\mathrm{R}$ & 28 & $\mathrm{R}$ & 17 & $\mathrm{R}$ \\
\hline H 1 & 15 & $\mathrm{R}$ & $\mathrm{R}$ & $\mathrm{R}$ & 31 & $\mathrm{R}$ & 18 & 25 \\
\hline H 2 & 23 & $\mathrm{R}$ & $\mathrm{R}$ & $\mathrm{R}$ & $\mathrm{R}$ & $\mathrm{R}$ & $\mathrm{R}$ & 34 \\
\hline B 1 & 22 & $\mathrm{R}$ & $\mathrm{R}$ & 15 & 14 & $\mathrm{R}$ & 20 & 26 \\
\hline B 2 & 22 & $\mathrm{R}$ & $\mathrm{R}$ & 12 & 30 & $\mathrm{R}$ & 20 & 25 \\
\hline $\mathrm{O} 1$ & 18 & $\mathrm{R}$ & $\mathrm{R}$ & $\mathrm{R}$ & 35 & $\mathrm{R}$ & 16 & 32 \\
\hline B 1 & $\mathrm{R}$ & $\mathrm{R}$ & $\mathrm{R}$ & $\mathrm{R}$ & 24 & $\mathrm{R}$ & $\mathrm{R}$ & 30 \\
\hline E 1 & 20 & $\mathrm{R}$ & $\mathrm{R}$ & $\mathrm{R}$ & 25 & $\mathrm{R}$ & 24 & 20 \\
\hline E 2 & 28 & $\mathrm{R}$ & $\mathrm{R}$ & $\mathrm{R}$ & $\mathrm{R}$ & $\mathrm{R}$ & $\mathrm{R}$ & 38 \\
\hline
\end{tabular}

KEY: CAZ= Ceftazidime, CRX= Cefuroxime, GEN= Gentamicin, CXM= Cefixime, OFL= Ofloxacin, AUG= Augmentin, NIT= Nitrofurantoin, CPR= Ciprofloxacin

Table 4 and 5 shows the antibiotic susceptibility pattern of the bacterial isolates. Most of the organisms were resistant to antibiotics such as ceftazidime, cefuroxime, and augmentin while a few showed sensitive patterns and others, intermediate zones.

Picture 1 shows the agarose gel electrophoresis of plasmids harboured by bacterial isolates showed multiple plasmids, which is 5 bacterial isolates were $>1,000 \mathrm{bp}$ (Salmonella sp, Escherichia coli, Enterobacter, Staphylococcus aureus and Micrococcus sp). Bacillus sp plasmid was 100bp. Table 6 shows the antibiotic susceptibility patterns of bacterial isolates after curing. Previously resistant isolates were observed to be susceptible after curing. 


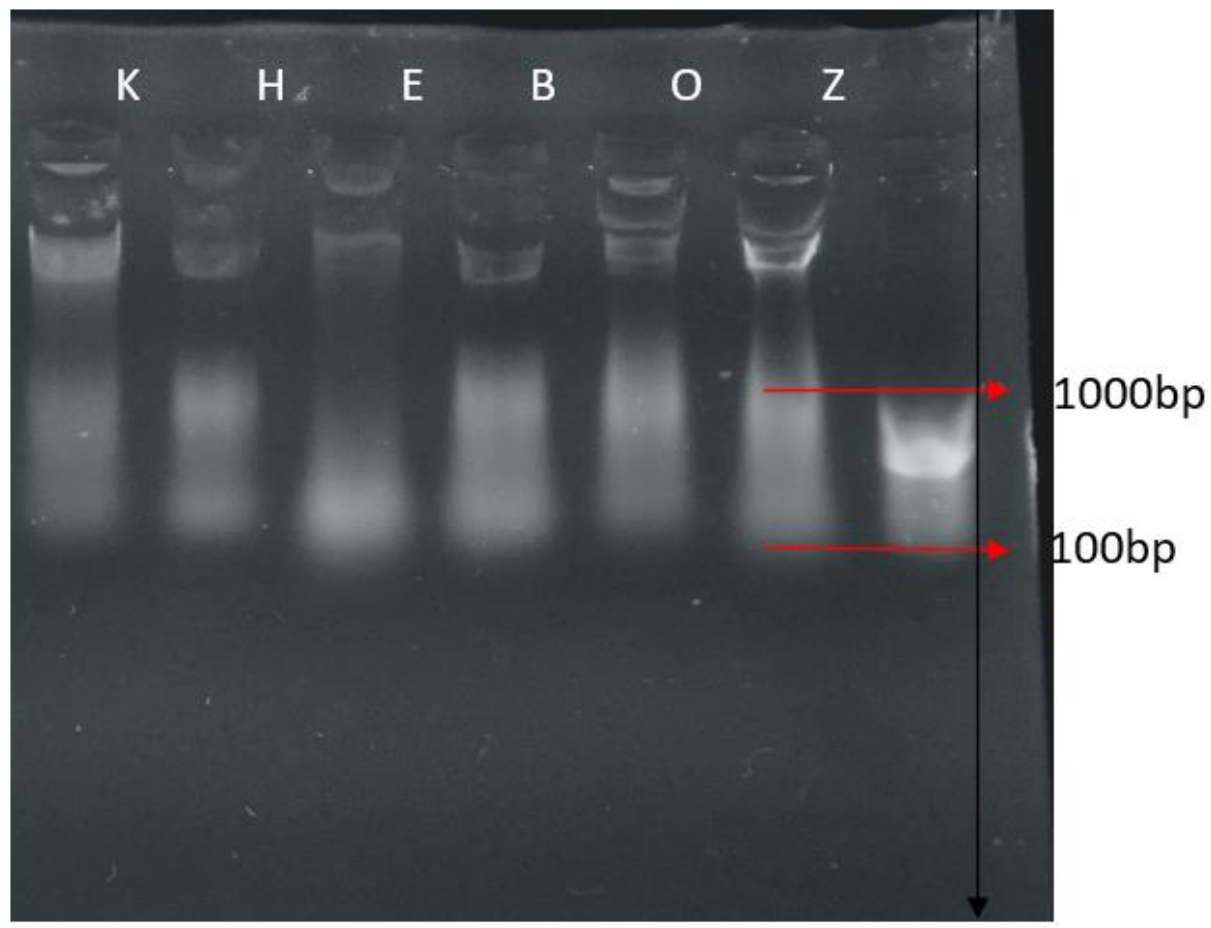

Fig. 1: Agarose Gel Electrophoresis of Plasmids Harbored by the Bacterial Isolates.

KEY: B = Salmonella sp., E = Escherichia coli, $\mathrm{H}=$ Enterobacter sp., $\mathrm{K}=$ Staphylococcus aureus, $\mathrm{A}=\mathrm{B}$ acillus sp., $\mathrm{O}=\mathrm{Micrococcus}$ sp., $\mathrm{Z}=\mathrm{DNA}$ ladder (100bp)

Table 6: Diameter of Zone of Inhibition (Mm) of the Antibiotics after Curing

\begin{tabular}{|c|c|c|c|c|c|c|c|c|}
\hline Isolates code & GEN & CAZ & CRX & CXM & OFL & $\mathrm{AUG}$ & NIT & CPR \\
\hline $\mathrm{A}$ & 25 & 25 & 20 & 20 & 30 & 0 & 25 & 28 \\
\hline $\mathrm{E}$ & 25 & 25 & 20 & 20 & 27 & 0 & 23 & 25 \\
\hline G & 28 & 30 & 20 & 25 & 30 & 0 & 25 & 30 \\
\hline K & 15 & 20 & 0 & 0 & 0 & 0 & 0 & 24 \\
\hline B & 20 & 20 & 13 & 26 & 30 & 0 & 10 & 30 \\
\hline $\mathrm{O}$ & 22 & 25 & 0 & 22 & 24 & 0 & 0 & 30 \\
\hline
\end{tabular}

KEY: E = Escherichia coli, $\mathrm{O}=$ Micrococcus sp., $\mathrm{B}=$ Salmonella sp., $\mathrm{A}=$ Bacillus sp., $\mathrm{K}=$ Staphylococcus aureus, $\mathrm{H}=\mathrm{Enterobacter}$ sp.

The presence of isolated microorganisms in this study could be attributed to unhygienic conditions during the preparation of the salad and rice. The same trend of bacterial contamination has also been reported by several workers. Fagade et al. (2005) isolated 2 bacterial and 3 fungal genera in a study on non-carbonated orange drink. Ikenebomeh \& Elohor (2005) reported the isolation of S. aureus, B. cereus, E. aerogenes and other organisms from fresh and roasted edible worms (Rhynchophorus phoenics) larvae collected from 5 locations in Delta and Edo state of Nigeria. The result of this present study is like previous reports by Desmarchelier et al. (1994), Nichols et al. (1999) \& Mensah et al. (2002). The presence of S. aureus and Salmonella sp. was also reported in sausages sold in Abeokuta and Benin City, Nigeria by Oluwafemi \& Simisaye (2005). Per Oluwafemi \& Simisaye (2005), most of the sausages being sold as ready-to-food pose health risk to consumers, making it imperative to institute sanitary measures during its production and sales.

The bacterial counts in this work it is like the bacterial count range of 1.6 to $8.0 \times 10^{4} \mathrm{CFU} / \mathrm{g}$ on nutrient agar as reported by Ikenebomeh \& Elohor (2005) in a similar study on the microbiological analysis of larvae. Though the microbial counts in this study are lower than the ranges but comparable with total aerobic count (3.5 to $4.0 \times 10^{6} \mathrm{CFU} / \mathrm{ml}$ ), reported in a similar study by Oluwafemi \& Simisaye (2005). From the results obtained in the present study, it was shown that the mean bacterial counts of the RTE rice and salad sample exceeded the maximum recommended standards by the International Commission on Microbiological Specification of Foods (ICMSF) (ICMSF 1978). The standard limits the mesophilic aerobic bacteria in RTE food products to a maximum of $10^{3} \mathrm{cfu}$. The bacterial counts are considerably high since no microorganism should be recovered in any food meant for human consumption (ICMSF 1978). Hence, RTE rice and salad sold to students by vendors in Benson Idahosa University are above the acceptable microbiological quality.

Most of the organisms found on these RTE salads are those commonly found in soil and water. However, indicators of faecal contamination; E. coli were reported in this study, the presence of other indicator organisms like Enterobacter aerogenes and Salmonella sp. might be the result of possible contamination during sales or unhygienic handling of salad during processing. The presence of these organisms reported in this study could pose health challenges as Salmonella sp. can cause typhoid in humans. In this study, the isolation of S. aureus and E. coli from salad samples indicates not only the preponderance of S. aureus on the skin but also the low level of standard of personal hygiene. The presence of S. aureus, a pathogenic organism of public health concern and significance in these ready to eat salad might have contaminated the salad from source because of handling by processors. Improper handling and improper hygiene might lead to the contamination of ready-to-eat food and this might eventually affect the health of the consumers (Okonko et al. 2008). The presence of E. coli and Salmonella in the ready to eat salad is an indication of possible fecal contamination of the processing water and poor hygienic processing practices. Unhygienic surroundings (where the foods were prepared and sold) like flowing sewage in open gutters, improper waste disposal system, and inadequate water supply attracts house-flies or fruit flies, probably further increases food contamination (Chumber et al. 2007).

Staphylococcus aureus is known to cause boils, abscesses, wound infections, toxic shock syndrome, pneumonia and other diseases (Willey et al. 2011). Bacillus cereus contributes immensely to food spoilage and food infection when contaminated food is consumed. 
Escherichia coli is known to cause illness ranging from urinary tract infection, diarrhea, and wound infections. Salmonella is known to cause food poisoning and typhoid fever, its presence in the ready to eat salad is of public health concern (Jay 2006).

It is therefore suggested that salad processors should be educated on the adverse effect of using untreated or polluted water for processing as these could serve as sources of faecal contamination. However, the vendors/retailers should observe strict hygienic measures so that they will not serve as a source of contamination of these ready to eat salads.

Resistance to multiple antibiotics was observed. Most of the isolates were sensitive to gentamicin and ciprofloxacin and resistance to augmentin and ceftazidime. In a similar study, Udo et al. (2008) reported the antimicrobial resistance profile of potential human pathogens isolated from fresh vegetable salad in Calabar, SouthSouth Nigeria.

Bacteria are intrinsically resistant to a wide range of antimicrobials of therapeutic use. They also can acquire and transfer genetic resistance markers, a process mediated by genes present in plasmids or transposons that facilitate their dissemination (Martin et al. 2005). The results provide a clear warning about high-level resistance to commonly used antibiotics among bacterial isolates from RTE salad, which has not previously been observed in Benin City, Edo State, Nigeria.

Plasmid profile showed that the isolates contained plasmid and the presence of the plasmid can be the reason for multi-resistance to antibiotic observed in this work. A similar report by Kalantar et al. (2011) showed the presence of plasmids of molecular sizes ranging from $1.4 \mathrm{~kb}$ to $4.5 \mathrm{~kb}$ among acute diarrhea-causing E. coli isolates showing resistance to ampicillin (A), chloramphenicol (C) and tetracycline $(\mathrm{T})$, and stated that these resistances are plasmid mediated.

There was a little reduction of resistance in some of the antibiotics while the resistance of the bacterial isolates to other antibiotics remained the same after curing as shown in Table 6. The resistance of the bacterial isolates to some of the antibiotics after curing may be attributed to the misuse and overuse of these antibiotics resulting in the emergence of antibiotics resistant strains. S. aureus was shown to continue to exhibit a wide range of antibiotic resistance even after curing thus indicating the possibility of its genes for resistance as being chromosomal and not plasmid borne. Resistance to Augmentin was observed before and after curing. Augmentin (an oral antibacterial combination consisting of amoxicillin and the beta-lactamase inhibitor, clavulanate potassium) is one of the most widely used antibiotics all over the world. The resistance of these isolates to Augmentin could be indicative that they possess $\beta$-lactamases capable to hydrolyzing amoxicillin in the presence of clavulanate.

\section{Conclusion}

The results of this study indicated that the ready-to-eat rice and salad samples sold in Benson Idahosa University contained microorganisms of public health importance. Hence, it is important to educate vendors/shop owners on the need for the good hygienic condition of the environment. Workers should be aware of the need for good sanitary habits and they should be educated on ways food gets contaminated. More supervision on food and food outlets should be carried out on campus. Furthermore, more research needs to be done on the isolates in this study to ascertain if they produce $\beta$-lactamases which is currently one of the leading causes of antibiotic resistance in bacteria.

\section{References}

[1] Tsang, D. (2002). Microbiological guidelines for ready to eat food. Road and Environmental Hygiene Department, Hongkong. Pp.115116.

[2] Mahakarnchanakul, W., Ontoun, W., Stonasaovapak, S., Pirapatrungsuriya, N, Choo-in, P., and Borisuit, T. (2010). Risk evaluation of popular ready-to-eat food sold in Bangkok. Asian Journal of Food Agro-Industry, 3(1): 75-81.

[3] Musa, O. I. and Akande, T. M. (2002). Effect of Health Education Intervention on food safety practice among food vendors in Ilorin. Sahel Medical Journal, 5: 120-124.

[4] Okeke, I. N., Lamikanra, A., Steinrück, H. and Kaper, J. B. (2000). Characterization of Escherichia coli strains from cases of childhood diarrhea in provincial southwest Nigeria. Journal of Clinical Microbiology, 38: 7-12.

[5] Osterblad, M., Pnsala, O., Peterzens, M., Heleniusc, H. and Huovien, P. (1999). Antimicrobial susceptibility of Enterobacteriaceae isolated from vegetables. Journal of Antimicrobial Chemotherapy, 43: 503-559. http://dx.doi.org/10.1093/jac/43.4.503.

[6] Pinegar JA, Cooke EM (1985). Escherichia coli in retail processed food. Journal of Hygiene (Lond.), 95 (1): 39-46. http://dx.doi.org/10.1017/S0022172400062264.

[7] Teuber, M. (1999). Spread of antibiotic resistance with food-borne pathogens. Cellular and Molecular Life Science, 56: 755-763. http://dx.doi.org/10.1007/s000180050022.

[8] Schoeder, C. M., White, D. G. and Meng, J. (2004). Retail meat and poultry as a reservoir of antimicrobial-resistant Escherichia coli. Food Microbiology, 21: 244-255.

[9] Goldstein, C., Lee, M. D., Sanchez, S., Hudson, C, Phillips, B, Register, B, Grady, M, Liebert, C, Summers, A, O, White, D. G, Maurer, J. J. (2001) Incidence of Class 1 and 2 Integrases in Clinical and Commensal Bacteria from Livestock, Companion Animals, and Exotics. Antimicrobial Agents and Chemotherapy, 45:723-726 http://dx.doi.org/10.1128/AAC.45.3.723-726.2001.

[10] Harrigan, W. F. and McCane, M. E. (1976). Laboratory Methods in Food and Dairy Microbiology, 1st Edition, Academic Press Inc., London, pp. $139-150$.

[11] Harley, J.P., and Prescott, L.M. (2002). Laboratory Exercises in Microbiology, 5th Edition, McGraw-Hill, New York. 449 pp.

[12] Chin S.C., Abdullah, N., Siang, T. W. and Wan, H.Y., (2005). Plasmid profiling and curing of Lactobacillus strains isolated from the gastrointestinal tract of chicken. Journal of Microbiology, 43 : $251-256$

[13] Fagade, O. E., Ogunjobi, A. A. and Oyelade, A. A. (2005). Microflora of noncarbonated orange drink. In: The Book of Abstract of the 29th Annual Conference and General Meeting (Abeokuta 2005) on Microbes as Agents of Sustainable Development, organized by Nigerian Society for Microbiology (NSM), UNAAB, from 6-10th November. $16 \mathrm{pp}$.

[14] Ikenebomeh, M. J. and Elohor, O. (2005). Microbiology of fresh and roasted edible worms' larvae (Rhynchophorusphoenics). In: The Book of Abstract of the 29th Annual Conference and General Meeting (Abeokuta 2005) on Microbes as Agents of Sustainable Development, organized by Nigerian Society for Microbiology (NSM), University of Agriculture, Abeokuta, from 6-10th November. $26 \mathrm{pp}$.

[15] Desmarchelier, P.M., Apiwathnasorn, C., Vilainerun, D., Watson, C., Johari, M. R., Ahmad, Z. and Barnes, A. (1994). Evaluation of the safety of domestic food prepared in Malaysia. Bulletin of World Health Organization, 72(6): 877-884

[16] Nichols, G. L., Little, C. L., Mithani, V. and De Louvois, J. (1999). The microbiological quality of cooked rice from restaurants and take-away premises in the United Kingdom. Journal of Food Protection, 62: 877-882.

[17] Mensah, P., Yeboah, M.D., Owusu, D.K. and Ablordey, A. (2002). Street foods in Accra, Ghana: how safe are they? Bulletin of the World Health Organization, 80 (7): 546- 554.

[18] Oluwafemi, F., and Simisaye, M. T. (2005). Extent of microbial contamination of sausages sold in two Nigerian cities. In: The Book of Abstract of the 29th Annual Conference and General Meeting (Abeokuta 2005) on Microbes as Agents of Sustainable Development, organized by Nigerian Society for Microbiology (NSM), University of Agriculture, Abeokuta, from 6-10th November, p. 28.

[19] ICMSF. (1978). Microorganisms in Foods: Their Significance and Methods of Enumeration, 2nd Edition, University of Toronto Press, Toronto

[20] Okonko, I.O., Ogunjobi, A. A., Fajobi, E. A., Onoja, B. A., Babalola, E. T. and Adedeji, A. O. (2008). Comparative studies and microbial risk assessment of different Ready-to-Eat (RTE) frozen seafoods processed in Ijora-olopa, Lagos State, Nigeria. African Journal of Biotechnology, 7(16): 2898-2901.

[21] Chumber, S. K., Kaushik, K. and Savy, S. (2007). Bacteriological analysis of street foods in Pune. Indian Journal of Public Health, 51(2): 114-116. 
[22] Willey, J. M., Sherwood, L. M., and Woolverton, C. J. (2011) Prescott's Microbiology, 8th Edition, McGraw-Hill, New York. pp. $969-971$

[23] Jay, J. M. (2006). Modern Food Microbiology, 6th Edition, Gaithersburg (MD), Aspen, London. pp. $679-680$.

[24] Udo S., Andy. I., Umo, A., and Ekpo, M., (2008). Potential human pathogens (bacteria) and their antibiogram in ready-to-eat salads sold in Calabar, South-South, Nigeria. The Internet Journal of Tropical Medicine, 5(2): 1

[25] Martin, B., Garriga, M., Hugas, M. and Aymerich, T (2005). Genetic diversity and safety aspects of Enterococci from slightly fermented sausages. Journal of Applied Microbiology, 98:1177-1190. http://dx.doi.org/10.1111/j.1365-2672.2005.02555.x.

[26] Kalantar, E., Soheili, F., Salimi, H., and Soltan, D.M. (2011). Frequency, antimicrobial susceptibility, and plas $\neg$ mid profiles of Escherichia coli pathotypes ob $\neg$ tained from children with acute diarrhea. Jundis $\neg$ hapur Journal of Microbiology, 4:23-28. 